\title{
EL DIARIO ABC Y LA DEPORTISTA ESPAÑOLA EN LOS JJ.OO.
}

\author{
Miguel Ángel Barbero González \\ Dr. en Periodismo. Diario ABC \\ mibarber@ucm.es \\ Fecha de recepción: Febrero 2016 \\ Fecha de aceptación: Abril 2016
}

http://dx.doi.org/10.15366/citius2016.9.1.003

\section{Resumen:}

Del 5 al 21 de agosto de 2016 se celebrarán los Juegos Olímpicos de Río, donde el interés por las actividades deportivas femeninas españolas seguirá creciendo, si continúa la progresión de buenos resultados de las últimas citas. Precisamente, para analizar lo que ha sido esta evolución en las citas olímpicas vamos a centrarnos en el estudio de las informaciones femeninas en todos los Juegos Olímpicos en el Diario ABC, el más veterano de los de tirada nacional. Esto nos va a permitir estudiar el tratamiento informativo que se les ha dado a estas deportistas a lo largo de la historia. Dado que la primera aparición femenina sucedió en París 1924, este periódico es ideal para este fin. Se han analizado todas las páginas dedicadas a los Juegos Olímpicos en los que ha habido representación femenina española (2.770, desde París 1924 hasta Londres 2012) y contabilizado sus resultados de modo cuantitativo, tanto por deportes como por espacio, y cualitativo, por la relevancia de las mismas.

Las conclusiones indican que a mayor inversión en deporte femenino en la sociedad y en las federaciones hay mejores resultados y que, cuando estos llegan, la atención informativa es mayor. Al venderse hoy en día la información deportiva como un espectáculo, las medallas siempre son un activo, sean masculinas o femeninas. Ya no se deja de lado a las mujeres en los MM.CC. por su condición de género; hoy en día el público lo que quiere son éxitos, vengan de donde vengan. Se las ve como unas competidoras más $\mathrm{y}$, si lo hacen bien, se ganan su sitio a pulso.

Palabras clave: Mujer, deporte, deportistas, Juegos Olímpicos, olimpismo, medallas, periodismo, ABC. 


\title{
Title: ABC NEWSPAPER AND SPANISH SPORTSWOMEN IN OLYMPIC HISTORY
}

\begin{abstract}
:
Next August 5th-21st will take place the Rio Olympic Games, where interest in the Spanish Olympic female Team is expected to increase, due to the great results given. That is precisely why we are going to analyze the evolution in the Olympics through the female information published in the daily Diario $A B C$, the most veteran among the national newspapers. We will be able to study the informative treatment those sportswomen have received thought the History. The first time a Spanish female athlete competed in the Olympics was in Paris 1924, and this newspaper fits perfectly with this topic. All the pages with Spanish female representation in the Olympics (2.770 from 1924 till 2012) have been checked and the results have been analyzed both quantitative (sports and measureable area) and qualitative (relevance).
\end{abstract}

Results show that the more money Society and the Federations invest in female sports, better results are achieved and therefore more media attention is obtained. Nowadays, sporting news is sold as a show and medals are always positive news. Women are not brush aside in the Games by their gender; everyone wants victories and successes, no matter who gets them, men or women. Ladies are seen as competitors, and if they do well, they reach their place by themselves.

Keywords: Women, Sport, sportswomen, Olympics, Olympism, Journalism, ABC, medals

\section{INTRODUCCIÓN}

El trabajo que aquí se presenta forma parte de la Tesis Doctoral cuyo objeto de estudio responde al título con el que se presenta. Los datos que han formado parte de las unidades de análisis de nuestra investigación, han partido de las páginas de los periódicos. El marco temporal vino determinado claramente por la primera información olímpica femenina en $\mathrm{ABC}$ (15 de julio de 1924) y la última (14 de agosto de 2012).

Para la realización de este trabajo se analizaron 15 ediciones olímpicas en las páginas de ABC: la de 1924 y las catorce comprendidas entre 1960 y 2012, ininterrumpidamente. 


\section{EL DEPORTE OLÍMPICO FEMENINO ESPAÑOL EN EL DIARIO ABC}

\subsection{Los Juegos de París 1924}

\subsubsection{Análisis cualitativo}

Los Juegos de París 1924 no se puede decir que fueran un ejemplo de organización. Por un lado las competiciones se desarrollaron durante tres meses (pues se aprovecharon los fastos de la Exposición Universal que se desarrollaba en esos momentos en la Ciudad Luz) y, por otro, la repercusión de las noticias era todavía bastante escasa y no existía el relumbrón de hoy en día. Por si fuera poco, el calendario de pruebas olímpicas estaba aún definiendo su futuro y no tenía mucho tirón para los aficionados. De hecho, el Comité Olímpico Español recurrió a una suscripción popular para enviar a Francia a los atletas.

Aun así, a la estela de la plata lograda en Amberes 1920, la selección de fútbol acudió como favorita, lo que motivó que $\mathrm{ABC}$ enviara a un enviado especial (Rubryk), que cubrió todos los acontecimientos. Sin embargo, la pronta eliminación de los españoles hizo que las portadas y páginas completas de información de los primeros días quedaran relegadas a sueltos o breves en las páginas de espectáculos (en esa época no había una sección deportiva como tal).

A medida que fueron sucediéndose las competiciones se fue escribiendo de boxeo, tiro, pelota, esgrima o polo, para volver a rehacer el interés cuando llegaron los "Juegos Atléticos" [sic] a partir de julio. Ésa fue la parte central de la edición olímpica francesa y ahí el finlandés Paavo Nurmi se erigió en la gran estrella (con una foto a media página incluida). Es muy destacable este hecho, pues a pesar de la dificultad de los medios técnicos de entonces el $\mathrm{ABC}$ dedicó tres días a informaciones gráficas y dos portadas con fotos a toda plana. Igualmente, hay referencia a los JJ.OO. con una viñeta de Xaudaró.

Otros deportes como la lucha, la natación, el remo, el waterpolo, los juegos ecuestres o la vela también tuvieron su espacio en el diario. También se informó de pelota vasca, deporte de exhibición en esta edición parisina.

El periódico se publicaba a diario (los lunes había una edición de tarde para respetar el descanso dominical), pero no todos los días se informaba de los deportes olímpicos. De hecho, entre el 23 de mayo y el 27 de julio sólo salieron notas en 37 días (en 57 páginas). 
Por lo que respecta a la información de las deportistas femeninas, hay que decir que es meramente testimonial. Sólo acudieron cuatro tenistas y se habló de ellas únicamente tres veces.

\subsubsection{Análisis cuantitativo}

Del total de espacio dedicado a la información olímpica en ABC en París $1924\left(10.640 \mathrm{~cm}^{2}\right)$, sólo se dedicaron a las mujeres $98 \mathrm{~cm}^{2}$, lo que supone un exiguo $0,92 \%$ (cuadro 10 ).

El total de mujeres participantes fue de 4, en una expedición de 100 personas $(4 \%)$.

\subsection{Los Juegos de Roma 1960}

\subsubsection{Análisis cualitativo}

El tratamiento informativo de los Juegos de Roma 1960 en ABC supuso un salto de calidad evidente con referencia a los primeros analizados, los de París 1924. El cambio principal es que ya existía una sección consolidada de Deportes y que las informaciones se cubrieron tanto por un enviado especial (Manuel Gómez Aróstegui), como por un corresponsal (Julián Cortés Cavanillas) y por agencias (Alfil y Mencheta). De ahí que la cobertura se mantuviera entre una y dos páginas a lo largo que casi todos los días. Las crónicas, como se anuncia, se enviaban telefónicamente.

Sin embargo, la ausencia de resultados destacados (sólo se logró un bronce en hockey masculino) y de estrellas españolas con opciones (en España todavía estábamos con los estragos de la postguerra y no se podía hacer inversiones en el deporte) hizo que tampoco se produjera un seguimiento excesivo de las distintas disciplinas. Aumentó el número total de deportistas (145 ante 100 en París) y de damas (11/4), lo que supuso un incremento en el porcentaje de participación femenina (pasó del $4 \%$ al 7’59\%). Sin embargo, a la hora de la repercusión en las letras o fotos impresas esto no se vio reflejado en absoluto. Pese a que en Roma se publicó casi un $50 \%$ más que en París $\left(15.478 \mathrm{~cm}^{2}\right.$ contra $\left.10.640 \mathrm{~cm}^{2}\right)$, la superficie femenina fue casi un tercio menor (28/98). Esto rebaja el porcentaje de $0,92 \%$ a $0,18 \%$. Pues sólo se habló en dos ocasiones de ellas: los días 27 de agosto y 1 de septiembre. Además, fueron referencias escuetas (7 líneas cada día) referidas a las nadadoras y tiradoras de esgrima. De las gimnastas, ni una palabra. En cuanto al lenguaje, se las mencionaba como "las chicas", en comparación con el "Sra. de Álvarez" de las crónicas de los años 20. 
En esta ocasión, como sucedió también en las citas siguientes, el periódico no se publicó los lunes. En cuanto al diseño de $\mathrm{ABC}$, continúaba con tres columnas aunque incorporaba ya anagramas y dibujos en las cabeceras de la sección. El tratamiento gráfico también se incrementó, pues se dieron dos portadas, dos medias páginas y cinco completas de fotografías. Igualmente, los grandes viñetistas también colaboraron, como en el caso de Mingote.

En cuanto al héroe de los Juegos, puede considerarse al etíope Abebe Bikila como tal, por su hazaña de ganar el maratón corriendo descalzo.

\subsubsection{Análisis cuantitativo}

Del total del espacio dedicado a la información olímpica en ABC en Roma $1960\left(15.478 \mathrm{~cm}^{2}\right)$, sólo se dedicaron a las mujeres $28 \mathrm{~cm}^{2}$, lo que supone un ínfimo $0,18 \%$.

El total de mujeres participantes fue de 11 , en una expedición de 145 personas $(7,49 \%)$.

\subsection{Los Juegos de Tokio 1964}

\subsubsection{Análisis cualitativo}

El tratamiento informativo de los Juegos de Tokio 1964 se mantuvo en una línea muy similar al de cuatro años antes en Roma. El aumento de la publicidad en la sección propició que cada día se ofrecieran un promedio de tres páginas desde la capital nipona, aunque el detalle de la superficie impresa es incluso ligeramente inferior al anterior $\left(14.376 \mathrm{~cm}^{2}\right.$ en Tokio por $15.478 \mathrm{~cm}^{2}$ en Roma). En este caso sólo hubo una firma responsable (Enrique Gilera), que en sus envíos avisaba que se transmitían por télex.

Al contrario de lo sucedido en Italia (donde se logró un bronce en hockey masculino), en esta ocasión no hubo metales para la expedición española, lo que hizo que la repercusión de los Juegos tampoco terminara de despuntar. Otros dos factores también influyeron en que esta edición no cuajase mucho a nivel popular: el menor número de participantes (la tercera parte que en 1960) y la diferencia horaria a la hora de transmitir los resultados.

Se puede considerar esta etapa como de estancamiento en cuanto a la repercusión femenina. Si bien es cierto que se mejoró con respecto a lo publicado en la anterior (un $0,81 \%$ de espacio con respecto a un $0,18 \%$ ), no se llegó ni siquiera a la cifra alcanzada en París $(0,92 \%)$ cuarenta años antes. La reducción 
drástica del número total de deportistas (50 ante 145 en Roma) y de damas (3/11) tampoco ayudó. El trío de nuestras representantes eran nadadoras.

Siguiendo en la línea de los Juegos de Roma, sólo se habló en tres ocasiones de ellas: los días 13, 16 y 18 de octubre. Fueron cuatro de las 47 páginas en las que hubo información olímpica de esa edición. Se ganó algo de repercusión los dos primeros días en cuanto a las líneas de texto (hay 24 el primer día y 4 el segundo), y fue en el último cuando se obtuvo una importante mejora: en la portadilla se hizo referencia al record nacional de Rita Pulido en los $400 \mathrm{~m}$. estilos en un sumario y luego se le ofrecieron las 32 primeras líneas de la crónica principal.

Como cuatro años atrás, el periódico no se publicó los lunes y la maquetación continuó con tres columnas, aunque con una cabecera de la sección nueva. En cuanto al tratamiento gráfico disminuyó levemente al perderse media página con respecto a Roma. En Tokio se dieron dos portadas, una media página y cinco completas de fotografías, más una viñeta de Mingote.

Entre los deportistas fue muy bien tratada la segunda victoria de Abebe Bikila en maratón y la gran marca del velocista Robert Hayes en los 100 metros lisos (9:9).

\subsubsection{Análisis cuantitativo}

Del total de espacio dedicado a la información olímpica en $\mathrm{ABC}$ en Tokio $1964\left(14.376 \mathrm{~cm}^{2}\right)$, sólo se dedicaron a las mujeres $116 \mathrm{~cm}^{2}$, lo que supone un pobre $0,81 \%$.

El total de mujeres participantes fue de 3, en una expedición de 50 personas $(6 \%)$.

\subsection{Los Juegos de México 1968}

\subsubsection{Análisis cualitativo}

El tratamiento informativo de los Juegos de México 1968 supuso un salto de calidad con respecto a los precedentes de Roma. Se consolidaron las tres páginas mínimas diarias a pesar de la diferencia horaria y se incrementó notablemente la parte impresa $\left(21.192 \mathrm{~cm}^{2}\right.$ por $15.478 \mathrm{~cm} 2$ en Roma). El enviado especial volvió a ser Enrique Gilera, con apoyos de la Agencia Alfil. 
A pesar de que se duplicó el número de participantes (103 por 50 cuatro años atrás), las medallas seguían sin llegar.

Sin embargo, para el deporte femenino supuso una evolución muy significativa. Aunque ésta fue una edición con una representación mínima de mujeres (2), la gran actuación de $\mathrm{M}^{\mathrm{a}}$ Paz Corominas rompió todos los moldes. Su séptimo puesto en los $200 \mathrm{~m}$. espalda fue el primer diploma de la era moderna (los de Lilí Álvarez en París se equipararon con posterioridad al no concederse físicamente entonces) y se le dio la importancia que merecía. Eso sí, eclipsada por el brillo de su compañera, la otra nadadora de la expedición, Pilar von Carnsten, no se ganó ni una línea en el diario. La presencia numérica en el papel pasó del paupérrimo $0,81 \%$ de Tokio a un esperanzador $2,14 \%$ de lo publicado. No se volvió a escribir tanto de mujeres en ABC hasta Los Ángeles 1984. Fueron informaciones en nueve de las 54 páginas con información olímpica en esta edición.

Como ya era tradicional, el periódico no se publicó los lunes y la maquetación continuó con tres columnas, con la misma cabecera de sección.

Con respecto a otras ediciones olímpicas, se perdieron los recursos gráficos (no hubo portadas y fotos sólo en las páginas de resumen de "Campeón") y las viñetas. Aparecieron, por vez primera, páginas completas dedicadas a compilar los resultados de cada jornada y el recuadro del medallero.

Las hazañas en el estadio Bob Beamon y Jim Hines fueron de las más destacadas.

\subsubsection{Análisis cuantitativo}

Del total de espacio dedicado a la información olímpica en $\mathrm{ABC}$ en México $1968\left(21.192 \mathrm{~cm}^{2}\right)$, se dedicaron a las mujeres $453 \mathrm{~cm}^{2}$, lo que supone un $2,14 \%$ de lo publicado (cuadro 10). El total de mujeres participantes fue de 2, en una expedición de 103 personas $(1,94 \%)$.

\subsection{Los Juegos de Múnich 1972}

\subsubsection{Análisis cualitativo}

El tratamiento informativo de los Juegos de Múnich 1972 fue espectacular con respecto a lo que era habitual en $\mathrm{ABC}$. Se publicaron un promedio de ocho páginas diarias por parte de cuatro redactores "in situ" más la ayuda de las 
agencias. El hecho de que el Príncipe Juan Carlos participara en la disciplina de vela disparó el interés del periódico monárquico por los Juegos, lo que motivó que se duplicara con creces el espacio dedicado a los mismos $\left(51.455 \mathrm{~cm}^{2}\right.$ por 21.192 $\mathrm{cm}^{2}$ en México 1968). La ausencia de diferencia horaria y el hecho de que se televisaran en directo y en color también aumentaron el interés. Como enviado especial repitió Enrique Gilera junto a Andrés Mercé Varela (enviado especial), Miguel Ángel Gozalo (corresponsal) y Pablo M. Laborda (colaborador), con apoyos de la Agencia Alfil.

En esta ocasión sí que hubo medallas para la delegación española (un bronce). Como curiosidad cabe indicar que se denominaban balonvolea al voleibol y polo acuático al waterpolo. La comodidad del viaje en Europa hizo que se incrementara el número de participantes (123 por 103, cuatro años atrás) y de mujeres en la expedición (5 por 2).

Sin embargo, el deporte femenino no salió muy beneficiado de la cita bávara. Ninguna de las deportistas obtuvo una buena posición (el decimotercer puesto de la arquera María Teresa Romero y su record nacional fueron lo más destacado).

La presencia numérica en el papel retrocedió del 2,14\% de México 68 al $0,83 \%$ de lo publicado (casi igual que ocho años antes en Tokio, $0,81 \%$ ). La principal razón del descenso fue la ausencia de buenos resultados, ya que en las primeras ocasiones en las que se hablaba de ellas (antes de ser eliminadas) por lo general se le dedicaban dos párrafos a cada una; pero claro, al no participar más, no había posibilidad de incrementar esa cifra. Aun así, en diez de los quince días analizados hubo referencias a nuestras deportistas. Las apariciones femeninas se dieron en 16 de las 125 páginas totales.

El periódico siguió sin la edición de los lunes y la maquetación continuó con tres columnas, con la misma cabecera de sección por tercera edición consecutiva. Se recuperó el tratamiento gráfico de los Juegos y el despliegue fue muy destacado: se ofrecieron fotos en 22 páginas (14 de ellas completas) y dos de viñetas de Mingote. Aparte, se le dedicaron cinco portadas. También se ofreció regularmente el recuadro del medallero y los resultados a página completa.

El héroe de los Juegos, deportivamente hablando, fue Mark Spitz, con sus siete medallas de oro. 


\subsubsection{Análisis cuantitativo}

Del total de espacio dedicado a la información olímpica en $\mathrm{ABC}$ en Múnich $1972\left(51.455 \mathrm{~cm}^{2}\right)$, se dedicaron a las mujeres $429 \mathrm{~cm}^{2}$, lo que supone un $0,83 \%$ de lo publicado. El total de mujeres participantes fue de 5, en una expedición de 123 personas $(4,07 \%)$.

\subsection{Los Juegos de Montreal 1976}

\subsubsection{Análisis cualitativo}

El tratamiento informativo de los Juegos de Montreal 1976 fue bastante bueno, en la línea de la edición precedente a pesar de la lejanía del desplazamiento (49.720 $\mathrm{cm}^{2}$ por $51.455 \mathrm{~cm}^{2}$ en Múnich 1972). Se publicaron unas siete páginas diarias por parte de dos redactores "in situ" más la ayuda de las agencias. Como enviados especiales repitieron Enrique Gilera y Andrés Mercé Varela con apoyos de las agencias Alfil, Pyresa y Mencheta.

La delegación española fue ligeramente menor que en Alemania (114 por 123), pero se duplicaron las mujeres en la expedición (11 por 5). Además, hubo doble alegría por las dos platas conseguidas. Sin embargo, la mayor representación femenina en Canadá no significó una duplicación de su información en las páginas de ABC. Al contrario, se quedó en los mismos niveles de Alemania $(0,86 \%$ por $0,83 \%$ de lo publicado). La principal razón del estancamiento fue la ausencia de buenos resultados (ni medallas ni diplomas). Sólo hubo referencias de nuestras féminas en ocho de los quince días analizados.

El periódico siguió sin la edición de los lunes y la maquetación continuó con tres columnas, ya sin la misma cabecera de sección. Se mejoró el aspecto visual, con más blanco entre columnas y menos publicidad.

El tratamiento gráfico fue importante: se daban un par de páginas diarias y en dos ocasiones viñetas recogidas de medios extranjeros. Aparte, se le dedicaron seis portadas. También se ofrecieron regularmente el recuadro del medallero y los resultados a página completa.

La heroína de los Juegos, deportivamente hablando, fue Nadia Comaneci, que se convirtió en la primera gimnasta perfecta y en la auténtica reina del evento. A un nivel inferior, también destacaron los atletas Alberto Juantorena y Lasse Viren. 


\subsubsection{Análisis cuantitativo}

Del total de espacio dedicado a la información olímpica en $\mathrm{ABC}$ en Montreal $1976\left(49.720 \mathrm{~cm}^{2}\right)$, se dedicaron a las mujeres $430 \mathrm{~cm}^{2}$, lo que supone un $0,86 \%$ de lo publicado. El total de mujeres participantes fue de 11, en una expedición de 114 personas $(9,65 \%)$.

\subsection{Los Juegos de Moscú 1980}

\subsubsection{Análisis cualitativo}

El tratamiento informativo de los Juegos de Moscú 1980 bajó bastante con respecto a los dos precedentes. El tinte político que adquirieron, con el boicot de los países pro estadounidenses, y los últimos coletazos de éxito del bloque comunista hicieron que en $\mathrm{ABC}$ no se echara el resto en su cobertura $\left(32.942 \mathrm{~cm}^{2}\right.$ por $49.720 \mathrm{~cm}^{2}$ de Montreal y $51.455 \mathrm{~cm}^{2}$ en Múnich 1972). De hecho, el enviado especial que se desplazó allí fue el responsable de la Sección de Internacional, Antonio Alférez, no el de Deportes. Contó con el apoyo de Andrés Mercé Varela (trabajador del Comité Olímpico Internacional) y con los de agencias, aunque no se firmaron sus informaciones.

La delegación española participante, sin embargo, fue la más numerosa de la historia nacional hasta entonces ( 156 personas), aunque se perdieron dos mujeres con respecto a Montreal 1976 (9 por 11). En el aspecto deportivo se consiguieron seis medallas. Fueron los mejores Juegos Olímpicos para el deporte español hasta ese momento.

Lamentablemente, el éxito y la repercusión se circunscribieron al campo masculino. Es cierto que se logró un diploma olímpico en natación, pero pasó totalmente desapercibido ante las medallas de los hombres. Se mantuvo el nivel porcentual en el espacio publicado $(0,85 \%$ por $0,86 \%$ en Canadá) pero se perdieron días de presencia ( 6 de los 15 , por 8 cuatro años antes). En cuanto a la aparición en páginas, la hubo en nueve de las 69 que se publicaron.

El periódico siguió sin la edición de los lunes y la maquetación continuó con tres columnas, sin cabecera de sección. El aspecto visual, sin embargo, era más confuso, al colocar el medallero y los resultados como texto corrido en columnas en vez de en páginas completas.

El tratamiento gráfico también descendió, con una página diaria durante trece de los quince días analizados, y se perdieron las viñetas. En cuanto a las 
portadas, siguieron siendo seis como en Montreal, pero en este caso sólo hubo una completa, el día de la inauguración.

La URSS y la RDA fueron los grandes triunfadores por equipos. En el plano deportivo, las medallas y los deportes de equipo españoles (que obtuvieron un cuarto y dos quintos puestos adicionales) y el declive de Nadia Comaneci, mal tratada por los jueces, como reiteradamente se explicó, fueron los hechos más destacados.

\subsubsection{Análisis cualitativo}

Del total de espacio dedicado a la información olímpica en $\mathrm{ABC}$ en Moscú $1980\left(33.579 \mathrm{~cm}^{2}\right)$, se dedicaron a las mujeres $421 \mathrm{~cm}^{2}$, lo que supone un $1,25 \%$ de lo publicado. El total de mujeres participantes fue de 9, en una expedición de 156 personas $(5,77 \%)$.

\subsection{Los Juegos de Los Ángeles 1984}

\subsubsection{Análisis cualitativo}

El tratamiento informativo de los Juegos de Los Ángeles 1984 aumentó de una manera espectacular con respecto a los anteriores. A pesar de estar nuevamente marcados por problemas políticos (en esta ocasión fueron los países pro comunistas los que hicieron el boicot) y por las dificultades económicas (no se desplazó a ningún redactor a Estados Unidos) y horarias, la cobertura duplicó con creces la de la edición anterior $\left(71,451 \mathrm{~cm}^{2}\right.$ por $\left.32.942 \mathrm{~cm}^{2}\right)$. Se aprovechó la presencia in situ de Andrés Mercé Varela (trabajador del Comité Olímpico Internacional y colaborador de $\mathrm{ABC}$ ) para firmar sus crónicas como enviado especial y el trabajo de las agencias Efe y AFP. Además, desde la redacción de Madrid se hizo un gran esfuerzo para cubrir diversas disciplinas, que salieron impresas con los seudónimos Jorge Castroverde y V. M. I.

Siguiendo la estela de apuesta deportiva vista en Moscú, la delegación española volvió a crecer (179 personas) y el número de mujeres que viajaron volvió a ser un record (16). También en el aspecto porcentual la participación femenina fue la más alta nunca vista $(8,94 \%)$. En el aspecto deportivo se perdió una medalla con respecto a cuatro años atrás, pero no se les pueden considerar unos malos Juegos: 5 preseas.

La expedición femenina acudió muy renovada, con quince de las dieciséis participantes como debutantes en unos Juegos. En el aspecto numérico el resultado 
volvió a ser el mismo (un diploma) pero la buena competición que desarrollaron las gimnastas hasta alcanzar ese sexto puesto (la mejor clasificación de siempre de una española) motivó que el incremento porcentual en el espacio publicado fuera abrumador (4,58 \% por $0,85 \%$ por en la URSS). En cuanto a días de presencia en las páginas, se habló de las nuestras en 13 de los 18 días analizados (por 6 de los 15 en Moscú). El número de páginas con presencia femenina fue de 39 de un total de 130 en general.

En esta ocasión el periódico ya salía los lunes, por lo que hubo más días de exposición que en ediciones precedentes (18). La maquetación se renovó y alternaba las páginas a tres columnas con otras a cuatro. Las páginas se trataban con más estilo y quedaban más claras las informaciones, con recuadros y despieces. Los resultados de los españoles, los generales y el medallero tenían su espacio propio y las fotografías ya se incluían regularmente en las páginas. Laura Muñoz (2) fue la más retratada.

El tratamiento gráfico fue importante. Se dieron diecisiete referencias en la sección gráfica aparte de las fotos que salían en la propia sección. Además, los lunes se publicaban unas caricaturas a toda plana de Juan Palacios y en la previa unas viñetas de Summers. En cuanto a las portadas, sólo fueron cinco (una menos que en Moscú).

En el plano deportivo triunfaron Carl Lewis, Michael Gross, Li Ning y los baloncestistas locales (Michael Jordan, Pat Ewing y compañía).

\subsubsection{Análisis cuantitativo}

Del total de espacio dedicado a la información olímpica en $\mathrm{ABC}$ en Los Ángeles $1984\left(71.451 \mathrm{~cm}^{2}\right)$, se dedicaron a las mujeres $3.273 \mathrm{~cm}^{2}$, lo que supone un $4,58 \%$ de lo publicado. El total de mujeres participantes fue de 16 , en una expedición de 179 personas $(8,94 \%)$.

\subsection{Los Juegos de Seúl 1988}

\subsubsection{Análisis cualitativo}

El tratamiento informativo de los Juegos de Seúl 1988 en ABC (72.970 $\mathrm{cm}^{2}$ ) aumentó ligeramente con respecto a los de Los Ángeles $\left(71.451 \mathrm{~cm}^{2}\right)$ y se colocó como el más seguido hasta ese momento. Por primera vez en los últimos años no hubo problemas políticos de boicots y la presencia de la Infanta Cristina en la expedición española motivó que se le dedicara un gran espacio en el diario. Al 
igual que sucedió cuatro años atrás, por las dificultades económicas y horarias no se desplazó a ningún redactor in situ. Eso sí, se aprovechó de nuevo la presencia de Andrés Mercé Varela (trabajador del Comité Olímpico Internacional y colaborador de $\mathrm{ABC}$ ) para firmar sus crónicas como enviado especial. El resto de las amplias informaciones (se publicaron una media de ocho páginas diarias) se cubrieron desde la redacción de Madrid (salvo la vela en Pusán por EFE) sin reflejar ninguna firma.

Siguiendo la norma de las anteriores ediciones, la delegación española volvió a crecer (216 personas por 179 en 1984) y el número de mujeres que viajaron volvió a ser un record (31 por 16). Lógicamente, en el aspecto porcentual también la participación femenina subió a su punto más alto (14,35\%). En el aspecto deportivo, España perdió una medalla con respecto a cuatro años atrás (4), pero al ser los primeros Juegos en los últimos doce en los que asistieron los mejores deportistas del mundo hay que considerarlo como un éxito.

La expedición femenina acudió renovadísima, con treinta de las treinta y una participantes como debutantes en unos Juegos. En el aspecto numérico hubo dos diplomas olímpicos y el hecho de que la Infanta Cristina fuera integrante del equipo español y abanderada (actuó en una única regata y tuvo que retirarse por avería) hizo que la atención se disparara. Tanto que el espacio publicado casi duplicó porcentualmente al de Los Ángeles ( $8,37 \%$ por 4,58 \%). En cuanto a días de presencia en las páginas, se habló de las nuestras casi todos los días (en 17 de los 18) por 13 de 18 en Estados Unidos. Por lo que respecta al número de páginas, hubo presencia femenina en 67 de 142 que se publicaron $(47,18 \%)$.

Al igual que en la edición anterior, la maquetación alternaba las páginas a tres columnas con otras a cuatro. Los resultados de los españoles, los generales y el medallero tenían su espacio propio, pero las fotografías no aparecieron regularmente en las páginas. Sí lo hacían en la sección gráfica. La Infanta Cristina fue la más fotografiada (3 veces).

El tratamiento gráfico fue importante. Se dieron veintiséis páginas en la sección gráfica (siete con protagonismo femenino) aparte de las fotos que salían en la propia sección. Además, se publicaron caricaturas de Juan Palacios. En cuanto a las portadas, volvieron a ser cinco, con una femenina (Infanta Cristina).

Lamentablemente el protagonista fue un tramposo (Ben Johnson), lo que no restó valor al triunfo en su lugar de Carl Lewis. También destacaron Sergei Bubka y Florence Griffth-Joyner en atletismo; Matt Biondi en natación, Steffi Graf en tenis o la URSS en baloncesto (con un Arvydas Sabonis pletórico). 


\subsubsection{Análisis cualitativo}

Del total de espacio dedicado a la información olímpica en ABC en Seúl $1988\left(72.970 \mathrm{~cm}^{2}\right)$, se dedicaron a las mujeres $6.106 \mathrm{~cm}^{2}$, lo que supone un $8,37 \%$ de lo publicado. El total de mujeres participantes fue de 31, en una expedición de 216 personas $(14,35 \%)$.

\subsection{Los Juegos de Barcelona 1992}

\subsubsection{Análisis cualitativo}

El tratamiento informativo de los Juegos de Barcelona 1992 en ABC fue espectacular. Los hechos de celebrarse la cita olímpica por primera vez en España, el apoyo incondicional del público y de la Casa Real y los resultados increíbles que se produjeron en el bando hispano hicieron que se cuadruplicase el espacio dedicado con respecto a Seúl $1988\left(266.902 \mathrm{~cm}^{2}\right.$ por $\left.72.970 \mathrm{~cm}^{2}\right)$. En esta ocasión no sólo no hubo problemas políticos de boicots, sino que el derrumbe del Telón de Acero propició la presencia de nuevos países del Este ante la desaparición de estados como la URSS o Yugoslavia. Participaron Lituania, Letonia, Estonia o Croacia junto a un Equipo Unificado e, incluso, atletas de manera independiente. Por si fuera poco, la eliminación del apartheid sirvió para que Sudáfrica presentara una selección sin restricciones, con Nelson Mandela en el palco.

En esta ocasión, el ABC “tiró la casa por la ventana” y montó un equipo especial para realizar una cobertura que les permitiera estar in situ en casi todas las competiciones. Julio Carlos Díez, José Manuel Cuéllar, Domingo Pérez, Pedro Sardina, José Antonio Lorén, Manuel Frías, Manuel Adrio y Juan Carlos Valero conformaron el bloque principal, con colaboraciones puntuales de Montse Jerez, José María Español, Isabel Capellá o J. C. Olivares desde Barcelona. También aparecieron informaciones firmadas por EFE o por redactores desde Madrid. Una aportación especial, además de las habituales columnas de opinión de Gilera o de Miguel Ors, fue la de los columnistas contratados ex profeso para la ocasión: JJ Armas Marcelo, José Luis Garci, Emiliano, Ladislao Kubala, Santiago Esteva, Juan A. Corbalán, Maisa Lloret, Cecilio Alonso, Javier Moracho, Toño Gorostegui y Antonio Garrigues.

Con respecto a la anterior edición, la delegación española casi duplicó sus integrantes (421 por 216 personas en 1988), mientras que el número de mujeres que viajaron se cuadruplicó (127 por 31). Lógicamente, en el aspecto porcentual también la participación femenina creció hasta su punto más alto, más del doble que cuatro años atrás $(30,17 \%$ por $14,35 \%)$. En el aspecto deportivo, España 
multiplicó exponencialmente el número de medallas (22 por 4) con respecto a cuatro años atrás, además de conseguir otro hito muy importante y no siempre valorado: 11 diplomas olímpicos. Además, por vez primera las féminas lograban subir al podio en ocho ocasiones y sumar once diplomas. Esto hizo que se pasase de un promedio diario de ocho páginas publicadas en Seúl a 25 en Barcelona.

La expedición femenina acudió renovadísima, con 115 de las 127 participantes como debutantes en unos Juegos. En el periódico se siguieron todas las disciplinas (también las de exhibición: Pelota, Hockey sobre Patines y Taekwondo) y las deportistas se ganaron el derecho a salir a la palestra con sus buenas actuaciones. Se vivieron momentos históricos como los de la primera medalla femenina, que obtuvieron un seguimiento antes impensable en un medio de comunicación español. En general, el espacio femenino publicado casi duplicó porcentualmente al de Seúl (13,15\% por 8,37\%). En cuanto a días de presencia en las páginas, se habló de las nuestras todos los días, mientras que en la anterior cita fueron en 17 de los 18. En total hubo mención femenina en 188 de las 459 páginas publicadas.

Al igual que en la edición anterior, la maquetación alternaba las páginas a tres columnas con otras a cuatro. La infografía fue la gran innovación estilística, con grandes gráficos explicativos. Los resultados de los españoles, los generales y el medallero tenían su espacio propio, pero las fotografías no aparecieron regularmente en las páginas. Lo hacían en su lugar las caricaturas. Sí que hubo un gran despliegue en la sección gráfica, con 33 páginas a lo largo de la quincena. La más retratada fue Arancha (19 veces), de un total de 53 fotos femeninas.

Además, se publicaron caricaturas Juan Palacios, Bernardo Olabarría, Manuel Mampaso, Fernando Rubio y Ángel Pinto. En cuanto a las portadas, fueron siete, con respecto a las cinco de las dos ocasiones anteriores, aunque tres femeninas (Miriam Blasco, Almudena Muñoz y Mariví González). La última jornada mereció un despliegue especial de 70 páginas (españoles en el podio, especial gráfica, los especialistas de $\mathrm{ABC}$ y los triunfadores de los JJ.OO.). Durante todos los días se habían dado todos los resultados y el medallero en páginas propias.

Los Juegos en general tuvieron un claro protagonismo del equipo NBA. También se consolidó la leyenda de Carl Lewis, que volvió a ser de oro en su tercera comparecencia. 


\subsubsection{Análisis cuantitativo}

Del total de espacio dedicado a la información olímpica en $\mathrm{ABC}$ en Barcelona $1992\left(266.902 \mathrm{~cm}^{2}\right)$, se dedicaron a las mujeres $35.066 \mathrm{~cm}^{2}$, lo que supone un $13,14 \%$ de lo publicado. El total de mujeres participantes fue de 127, en una expedición de 421 personas $(30,17 \%)$.

\subsection{Los Juegos de Atlanta 1996}

\subsubsection{Análisis cualitativo}

El tratamiento informativo de los Juegos de Atlanta 1996 en ABC fue bastante correcto, sobre todo porque tenía el precedente de los Juegos de Barcelona 1992 y no se iban a poder igualar los resultados en ningún caso. Sin embargo, la herencia de la cita catalana y el que España acudiera a Estados Unidos con aspiraciones en varias disciplinas hizo que el espacio dedicado no se resintiese demasiado $\left(168.695 \mathrm{~cm}^{2}\right.$ por $\left.266.902 \mathrm{~cm}^{2}\right)$, sobre todo si se compara con la cita inmediatamente anterior a la barcelonesa (Seúl 1988) cuando la repercusión fue de $72.970 \mathrm{~cm}^{2}$.

Lógicamente, hubo menos enviados especiales, aunque el equipo desplazado a Estados Unidos fue notable. Enrique Ortego, Domingo Pérez, Pedro Sardina, Manuel Frías y Xavier Prunés vivieron en persona las competiciones; también aparecieron informaciones firmadas por EFE, Afp, Dpa, Reuters o por redactores desde Madrid, ya fuera con el seudónimo S. D. o con el nombre del periodista (por lo general esto se hacía al cubrir la vuelta al aeropuerto de los deportistas). Una aportación especial, además de alguna columna de opinión de Gilera, fue la de los columnistas contratados ex profeso para la ocasión: Theresa Zabell, Cecilio Alonso, Javier Moracho, Toño Gorostegui y Pedro Antonio Martín Marín.

Con respecto a la anterior edición, la delegación española rebajó el número de sus integrantes (289 por 421 en 1992) pero aumentó considerablemente con respecto a Seúl (216), que debe ser la referencia más real; igualmente, descendió la cantidad de deportistas viajeras (95 por 127 en Barcelona), mientras que con relación a 1988 el número de mujeres se triplicó (95 por 31). Con la participación porcentual en la expedición, sin embargo, no sucede lo mismo: en comparación con los hombres participantes se incrementó la cifra femenina (32,87 por $30,17 \%)$. En este caso, la comparación con Seúl es tremenda, pues se duplica el porcentaje $(14,35 \%$ en 1988). 
En el aspecto deportivo, España brilló con luz propia en categoría femenina. A pesar de contar con 32 deportistas menos que cuatro años atrás, se mantuvo en las cifras de éxitos de entonces: 6 medallas por 8 en Barcelona y 10 diplomas olímpicos por 11. Esto hizo que se mantuviese un buen nivel informativo diario, en el que el promedio de páginas publicadas fue de 14,4, menos que las 25 de Barcelona, pero casi el doble de las 8 de Seúl. Todo esto motivó que el espacio femenino publicado superara incluso al de Barcelona (15,63\% por 13,15\%), con el componente de calidad añadido de que allí las mujeres ya aparecían exclusivamente por sus méritos deportivos y no sólo por el carácter novedoso y un tanto pintoresco de su presencia en Barcelona. En cuanto a días de presencia en las páginas, se habló de las españolas todos los días (19). En total hubo mención femenina en 149 de las 274 páginas publicadas $(54,38 \%)$, mejorando las 188 de $459(40,96 \%)$ de la cita barcelonesa.

Al igual que en la edición anterior, la maquetación alternaba las páginas a tres columnas con otras a cuatro. Se continuó apostando por la infografía (cada día iba una doble página espectacular) y por las fotografías en la sección, muchas de ellas en color. Los resultados de los españoles, los generales y el medallero tenían su espacio propio y desaparecieron las caricaturas. Aparte, hubo una buena presencia olímpica en la sección gráfica, con 37 páginas a lo largo de casi tres semanas. De ellas, en 17 las protagonistas de las imágenes fueron chicas. En total, contando las fotos de portada, sección gráfica y deportes, aparecieron 55 imágenes de las hispanas y la más retratada volvió a ser Arancha (15 veces). En cuanto a las portadas, fueron trece, cinco femeninas (cuatro de Arancha y una de gimnasia rítmica).

Las estrellas de los Juegos volvieron a ser el "Dream Team" y Carl Lewis, con su victoria en una cuarta comparecencia, aunque tuvo que compartir protagonismo con Michael Johnson y Donovan Bailey. Igualmente, la completa apertura al profesionalismo en todos los deportes motivó con grandes estrellas mundiales como Miguel Induráin, Andre Agassi o Aleksandr Popov también dieran brillo con sus triunfos a los Juegos.

\subsubsection{Análisis cuantitativo}

Del total de espacio dedicado a la información olímpica en $\mathrm{ABC}$ en Atlanta $1996\left(168.695 \mathrm{~cm}^{2}\right)$, se dedicaron a las mujeres $26.368 \mathrm{~cm}^{2}$, lo que supone un $15,63 \%$ de lo publicado. El total de mujeres participantes fue de 95 , en una expedición de 289 personas $(32,87 \%)$. 


\subsection{Los Juegos de Sídney 2000}

\subsubsection{Análisis cualitativo}

El tratamiento informativo de los Juegos de Sídney 2000 en ABC fue espectacular y se convirtió en el más importante realizado por el Diario hasta ese momento. Aprovechando la reconversión realizada de cara al nuevo milenio se le dedicó un suplemento exclusivo de 24 páginas diarias, lo que elevó el total publicado a $282.172 \mathrm{~cm}^{2}$, una cifra que superó incluso los mágicos $266.902 \mathrm{~cm}^{2} \mathrm{de}$ Barcelona 92 y dejó pequeños los $168.695 \mathrm{~cm}^{2}$ de la cita precedente de Atlanta 96 . A pesar de tratarse de una competición en las Antípodas, con el problema logístico y de horario que ello supone para un diario español, se realizó un gran esfuerzo editorial.

Lógicamente, por motivos económicos siguió descendiendo el número de enviados especiales, que quedó reducido a tres: Domingo Pérez, Manuel Frías y Xavier Prunés; igualmente, aparecieron informaciones firmadas por EFE, por Agencias y por redactores desde Madrid. Se siguió cubriendo la vuelta al aeropuerto de los deportistas y se incrementó el número de columnistas de opinión. Aparte de redactores de la casa como Enrique Ortego, Ignacio Torrijos o Julio Carlos Díez, también aparecieron columnistas contratados ex profeso para la ocasión como el escritor Martín Casariego o los deportistas Mari Paz Corominas, Jesús Carballo, Carlos Marchena, Javier Moracho y Fermín Cacho.

Con respecto a la anterior edición, la delegación española aumentó el número de sus integrantes (323 por 289 en 1996) y la cantidad de deportistas viajeras (105 por 95). Con la participación porcentual en la expedición, sin embargo, no sucedió lo mismo: en comparación con los hombres participantes descendió ligeramente la cifra femenina $(32,51 \%$ por $32,87 \%)$.

En el aspecto deportivo, España bajó un tanto el nivel en categoría femenina. A pesar de contar con 10 deportistas más que cuatro años atrás, continuaron en descenso las cifras de preseas: 4 medallas (por 6 en Atlanta y por 8 en Barcelona); sin embargo, se duplicaron los diplomas (20, por 10 y 11 en las anteriores). Esto hizo que se mantuviese un gran nivel informativo diario, en el que un promedio de páginas publicadas un tercio mayor que en Atlanta $(21,9$ por 14,4$)$.

El espacio femenino publicado, sin embargo, aunque aumentó en cifras globales $\left(36.914 \mathrm{~cm}^{2}\right.$ por $26.368 \mathrm{~cm}^{2}$ en Atlanta y superó a los míticos $35.066 \mathrm{~cm}^{2}$ de Barcelona) descendió en porcentaje $(13,08 \%)$ con respecto a Atlanta $(15,63 \%)$ y Barcelona $(13,15 \%)$. En cuanto a jornadas de presencia en las páginas, se habló 
de las deportistas españolas todos los días (17). En total hubo mención femenina en 158 de 375 páginas publicadas, que superó ligeramente lo conseguido en Atlanta en términos netos (149 de 274$)$ pero descendió en los porcentuales $(42,13 \%$ por $54,38 \%)$.

En el suplemento de 24 páginas existía una portadilla con foto a toda página y la sección se llamaba "Especial Sídney 2000". En esta ocasión, la maquetación ya se puede considerar completamente "moderna". Se integran perfectamente en las páginas los textos, imágenes e infografías y se juega con el color en casi todas ellas. Se abandonaron definitivamente las tres columnas y se obtuvieron unas páginas mucho más limpias. Los resultados de los españoles, los generales y el medallero tuvieron su espacio propio. En cuanto a las imágenes, contando las fotos de portada, portadilla y suplemento, aparecieron 77 imágenes de las hispanas (22 más que en Atlanta) de un total de diez disciplinas diferentes. La más retratada en esta ocasión fue Nina Jivaneskaia (11). En cuanto a las portadas, fueron sólo tres, con una mención a Isabel Fernández y Nina.

Las estrellas de los Juegos fueron el gimnasta Alexei Nemov, el atleta Michael Johnson y los nadadores Jim Thorpe e Inge de Bruijn.

\subsubsection{Análisis cuantitativo 2000}

Del total de espacio dedicado a la información olímpica en ABC en Sídney $2000\left(282.172 \mathrm{~cm}^{2}\right)$, se dedicaron a las mujeres $36.914 \mathrm{~cm}^{2}$, lo que supone un $13,08 \%$ de lo publicado. El total de mujeres participantes fue de 105 , en una expedición de 323 personas $(32,51 \%)$.

\subsection{Los Juegos de Atenas 2004}

\subsubsection{Análisis cualitativo}

El tratamiento informativo de los Juegos de Atenas 2004 en ABC fue bastante bueno, aunque la coyuntura económica por la que atravesaba el Diario no permitió un despliegue tan espectacular como el de la edición anterior. En esta ocasión no se editó un suplemento exclusivo, sino que la sección especial "Atenas 2004" contó con 14,26 páginas de promedio. Esta reducción de papel motivó una disminución en los centímetros cuadrados publicados, que fueron 193.057 en relación a los $282.172 \mathrm{~cm}^{2}$ de Sídney 00 .

Por motivos económicos siguió descendiendo el número de enviados especiales, que quedó reducido a dos: Domingo Pérez y Manuel Frías. Sin 
embargo, esto no significó una merma en las informaciones, ya que el equipo se completó con Begoña Castiella (corresponsal) y los enviados especiales de Vocento Jon Agiriano, Amador Gómez y J. Gómez Peña. Igualmente, aparecieron textos firmados por EFE, por Agencias y por redactores desde Madrid. Se incrementó también el número de columnistas de opinión con redactores de Deportes como Pedro Sardina o José Carlos Carabias y de otras secciones como Manuel de la Fuente, Juan Mari Gastaca o Álvaro Martínez; por supuesto, se siguió contando con firmas externas como las de las escritoras Paula Izquierdo, Almudena Guzmán o Ely del Valle y las de deportistas como Javier Moracho o Íker Martínez.

Con respecto a la anterior edición, descendió ligeramente el número de integrantes de la delegación española (316 por 323 en 2000), mientras que subió espectacularmente la cantidad de deportistas viajeras (140 por 105). Es la mayor cifra de participantes femeninas de la historia, lo que motivó que se denominara a los de Atenas "Los Juegos de la Mujer". Igualmente, la participación porcentual en la expedición en comparación con los hombres participantes aumentó a un espectacular $44,30 \%(32,51 \%$ en 2000), muy cerca de la paridad total. El protagonismo femenino se notó desde el principio, ya que Isabel Fernández fue la abanderada española en el desfile inaugural.

En el aspecto deportivo, España incrementó mucho el nivel en categoría femenina. El aumento de deportistas (35 más que en Sídney) se vio recompensado con dos medallas más que en Australia (6 por 4) y un llamativo número de diplomas ( 25 por 20$)$, la cantidad más elevada conseguida hasta entonces. La única nota negativa es que, en aquella ocasión, no se consiguió ninguna presea dorada, pero el balance global de nuestras chicas fue más que positivo. Lograron mantener el interés a lo largo de los Juegos y Beatriz Ferrer-Salat se convirtió en la reina de la expedición con sus dos medallas. Los comentarios de resumen fueron que se había recuperado el nivel de Barcelona 92. Esto hizo que, pese a que se perdió presencia en cantidad con respecto a la edición anterior $\left(26.437 \mathrm{~cm}^{2}\right.$ por 36.914 $\left.\mathrm{cm}^{2}\right)$ aumentase el porcentaje $(13,69 \%$ por $13,08 \%)$ con respecto a Sídney 00 y se convirtiera en el segundo con mejor cobertura por detrás de Atlanta (15,63\%). En cuanto a jornadas de presencia en las páginas, se habló de las deportistas españolas todos los días (19). En total hubo mención femenina en 140 de las 271 páginas publicadas. Con respecto a Sídney (158 de 375) se perdieron 18 páginas en términos absolutos, pero aumentó ampliamente el porcentaje $(51,66 \%$ por 42,13 $\%)$. Es decir, que en más de la mitad de las páginas se escribió de deporte femenino español.

En cuanto al estilo de $\mathrm{ABC}$, la maquetación volvió a retocarse. Se observa una portada más visual, con despliegue de colores e informaciones (ya no hay un 
tema único). Aunque no se juega con la infografía y el color tanto como cuatro años antes, se integraron perfectamente en las páginas los textos, imágenes e infografías. Los resultados de los españoles, los generales y el medallero tuvieron su espacio propio.

En cuanto a las imágenes, contando las fotos de portada, portadilla y suplemento, aparecieron 56 imágenes de las hispanas (19 menos que en Sídney y una más que en Atlanta, que es la referencia más real). La más retratada en esta ocasión fue Beatriz Ferrer-Salat (8). En cuanto a las portadas, hubo presencia olímpica casi a diario (17 de las 19 analizadas), muy por encima de las tres de Sídney. Pese a no haber ninguna completa, tuvieron protagonismo Isabel Fernández como abanderada y María Quintanal al ser la primera medallista.

Las estrellas de los Juegos fueron el atleta Hiradich El Guerrouj y el nadador Michael Phelps.

\subsubsection{Análisis cuantitativo}

Del total de espacio dedicado a la información olímpica en $\mathrm{ABC}$ en Atenas $2004\left(193.057 \mathrm{~cm}^{2}\right)$, se dedicaron a las mujeres $26.437 \mathrm{~cm}^{2}$, lo que supone un $13,69 \%$ de lo publicado. El total de mujeres participantes fue de 140, en una expedición de 316 personas $(44,30 \%)$.

\subsection{Los Juegos de Pekín 2008}

\subsubsection{Análisis cualitativo}

El tratamiento informativo de los Juegos de Pekín 2008 en ABC tuvo un alto nivel, pese a que el problema económico por el que atravesaba el Diario no permitió enviar un contingente muy elevado de periodistas (tres). Sin embargo, se realizó un esfuerzo editorial importante y se aumentó el número de páginas que se le dedicaron diariamente (17,67 de promedio) en relación con las de Atenas 2004 $(14,26)$. Esto motivó que creciera el número de centímetros cuadrados publicados, que fueron 232.333 en relación con los 193.057 de la cita griega. Este crecimiento colocó a la edición pekinesa como la tercera más seguida en la historia olímpica de $\mathrm{ABC}$ hasta el momento.

Los desplazados fueron dos informadores con amplia experiencia (Manuel Frías y Pedro Sardina) y otro que debutaba (Enrique Yunta). Siguiendo el modelo iniciado en Grecia cuatro años antes, el equipo se completó con el corresponsal Pablo M. Díaz y los enviados especiales de Vocento Jon Agiriano, Amador Gómez 
y J. Gómez Peña. Igualmente, aparecieron textos firmados por Agencias, ABC y, lo que desde entonces empezó a ser una nota habitual en el periódico, por redactores desde Madrid, con o sin data en las informaciones. Se incrementó también notablemente el número de columnistas de opinión y esta vez se optó por abrir enormemente el abanico. Visualmente se incorporó la foto del firmante junto con su cargo y a lo largo de los días aparecieron comentarios desde todos los sectores: Fernando Castro Flórez (escritor); Mariano Rajoy, Mercedes Coghen y Jaime Lissavetzky (políticos); José Calabuig (médico), Javier Mínguez, Javier García Cuesta y Javier Duarte (técnicos) y Javier Moracho, José Luis Llorente, Samuel Sánchez, Jordi Arrese, Pedro Campos, Herminio Menéndez y Jackson Richardson (deportistas).

En el aspecto deportivo, se notó cuantitativa y cualitativamente el descenso de participantes españoles en estos Juegos. A causa de la crisis y de la nueva política deportiva implantada en este ciclo, con respecto a Atenas 04 la expedición total bajó de 316 a 285 personas y la de mujeres de 140 a 122. Esto influyó en que la cosecha de trofeos fuera menor. En el total se bajó de 20 a 18 y en el campo femenino de 6 a 4 . En cuanto al número de diplomas, la cosecha global descendió de 50 a 36 (de 25 a 15). Al igual que sucedió en la edición previa, la presea dorada volvió a resultar esquiva.

El balance global de nuestras chicas fue positivo, nació para el gran público una nueva heroína, Gemma Mengual, que consiguió las primeras medallas para la natación sincronizada. Esto hizo que aumentase el espacio que se les dedicó con respecto a la edición anterior $\left(31.051 \mathrm{~cm}^{2}\right.$ por $\left.26.437 \mathrm{~cm}^{2}\right)$ y que porcentualmente se mantuviera casi al mismo nivel $(13,36 \%$ por $13,69 \%)$ con respecto a Atenas 04. En cuanto a jornadas de presencia en las páginas, se volvió a escribir de las deportistas españolas todos los días analizados (18). En total hubo mención femenina en 170 de las 318 páginas. Con respecto a Atenas (140 de 271) se ganaron 30 páginas en términos absolutos y aumentó el porcentaje $(53,45 \%$ por $51,66 \%$ ). Es decir, que se volvió a escribir de deporte femenino español en más de la mitad de las páginas de $\mathrm{ABC}$.

En cuanto al estilo de $\mathrm{ABC}$, la maquetación volvió a retocarse ligeramente. La portada seguía siendo visual y colorida (con varios temas de actualidad, publicidad y promociones propias) y la información olímpica apareció casi a diario en recuadros con o sin foto; la infografía y el color tuvieron una preponderancia absoluta. La maquetación seguía siendo a cinco columnas, pero se siguen a menudo los textos de una página a otra. Desaparecieron los resultados de los españoles y el medallero tuvo su espacio propio. 
En cuanto a las imágenes, es importante destacar que, además de las propias de la portada y la sección, se recuperó la sección gráfica de las primeras páginas ("Enfoque"), donde hay un gran despliegue gráfico, con alarde de maquetación. Contando las fotos de Portada, Enfoque, Portadilla y Sección, aparecieron 78 imágenes de las hispanas (22 más que en Atenas), una marca nunca vista antes. La más retratada en esta ocasión fue Gemma Mengual (14).

En cuanto a las portadas, hubo presencia olímpica casi a diario (16 de las 18 analizadas), una menos que en Atenas, y femenina en ocho de ellas. Las españolas aparecieron en cuatro portadas (Olaberría, Ruano-Medina, equipo de natación sincronizada y Maribel Moreno) y una portadilla. El caso de Moreno merece capítulo aparte, ya que su protagonismo vino marcado por un positivo en el control antidopaje antes de empezar la competición. Las estrellas de los Juegos fueron el atleta Usain Bolt, el nadador Michael Phelps, el "Dream Team" de la NBA y los españoles Rafa Nadal y Pau Gasol. También acudieron otras figuras internacionales como Roger Federer o Alberto Contador.

\subsubsection{Análisis cuantitativo}

Del total de espacio dedicado a la información olímpica en ABC en Pekín $2008\left(232.333 \mathrm{~cm}^{2}\right)$, se dedicaron a las mujeres $31.051 \mathrm{~cm}^{2}$, lo que supone un $13,36 \%$ de lo publicado. El total de mujeres participantes fue de 122 , en una expedición de 285 personas (42,8\%).

\subsection{Los Juegos de Londres 2012}

\subsubsection{Análisis cualitativo}

El tratamiento informativo de los Juegos de Londres 2012 en ABC fue bastante bueno, aunque por el persistente problema económico arrastrado por el Diario no se pudiera llegar a las cifras extraordinarias que se marcaron en Sídney doce años antes, ni siquiera igualar las de Pekín de la edición anterior. Pese al esfuerzo editorial se redujo el número de páginas que se le dedicaron diariamente $(16,26$ de promedio) en relación con las de Pekín $08(17,67)$, lo que motivó que también bajara el número de centímetros cuadrados publicados, que fueron 226.125 en relación con los 232.333 de la cita china. Los Juegos de Londres se situaron en el cuarto puesto global del seguimiento olímpico de ABC en la historia.

Siguiendo el modelo de los últimos años, fueron tres los enviados especiales al evento: Enrique Yunta (ya con experiencia previa) y los debutantes David Álvarez (jefe de Sección) y Tomás González-Martín (sólo para fútbol). 
Desde que Enrique Ortego acudió a Atlanta 96 ningún máximo responsable de Deportes había asistido a una cita olímpica. En la capital inglesa contaron con el apoyo del corresponsal Borja Bergareche y de los periodistas de Vocento Jon Agiriano, J. Gómez Peña e Íñigo Gurruchaga; puntualmente aparecieron informaciones de la colaboradora Ana Mellado (Servicio Especial). Igualmente, numerosos textos firmados por $\mathrm{ABC}$ y por redactores desde Madrid, con o sin data en las informaciones. En cuanto a los columnistas, fueron menos que en ocasiones anteriores y se dividieron mejor entre los que pertenecían a la Casa y los externos. Los primeros fueron Ángel Expósito (Director de ABC), Manuel Erice, Jesús Lillo y Jaime González, José Manuel Cuéllar, Pedro Sardina, Borja Bergareche y Rosa Belmonte. Entre los columnistas esporádicos destacaron Carlus Padrissa (dir. artístico); Theresa Zabell, Jorge Garbajosa, Fermín Cacho, Ángel David Rodríguez y Herminio Menéndez (deportistas) y José Luis Sáez (federativo). En todos los casos, incluidos los redactores, aparecía la foto del firmante junto con su cargo.

En el aspecto deportivo continuó la política de austeridad impuesta por el COE y las Federaciones y volvió a descender el número de expedicionarios, que con respecto a Pekín 08 bajó de 285 a 282 personas y el de mujeres de 122 a 113 . Sin embargo, esto apenas se notó en la cosecha de trofeos. En el total de medallas se bajó de 18 a 17 y en el número de diplomas de 36 a 30 (de 15 a 9 los femeninos); ahora bien, la explosión en los metales obtenidos por las mujeres fue apoteósica: se pasó de 4 a 11 (la más alta de la historia) y, lo que es más importante, se superó por primera vez a los hombres en este apartado (11 a 6). Con este balance (11 medallas de las 17) se alcanzó un porcentaje record del 64,71\% de éxito femenino.

Con este nivel de atención, el espacio que se les dedicó al deporte femenino experimentó una subida increíble: pasó de $31.051 \mathrm{~cm}^{2}$ a 51,721 y porcentualmente casi se duplicó $(22,87 \%$ por $13,36 \%)$ con respecto a Pekín 08. Esta es la mayor cifra de todos los tiempos y representa que casi la cuarta parte de las informaciones olímpicas en $\mathrm{ABC}$ tenían a la mujer como protagonista. Esta notoriedad se concretó en 33 páginas con información exclusivamente femenina en Londres 12. En cuanto a jornadas de presencia en las páginas, se volvió a escribir de las nuestras todos los días analizados (19). Curiosamente, hubo mención femenina en menos páginas que en Pekín (157 por 179) en un total de 309 por 318, lo que hizo que descendiera el porcentaje $(50,81 \%$ por $56,29 \%)$. Pese a ello, se volvió a escribir de deporte femenino español en más de la mitad de las páginas de $\mathrm{ABC}$.

En cuanto al estilo de $\mathrm{ABC}$, la maquetación volvió a retocarse ligeramente. La portada fue más visual y menos colorida (con un tema de actualidad, alguno 
secundario y publicidad) y la información olímpica apareció casi a diario con distintos tamaños en función de los éxitos. Tuvo menos preponderancia la infografía en las informaciones, en las que entonces se jugó más con fotos a gran tamaño o silueteadas. La maquetación volvió a ser a cuatro columnas, pero se siguieron a menudo los textos de una página a otra.

En cuanto a las imágenes, volvieron a ser las grandes protagonistas de los Juegos. Se ofreció una gran información gráfica, tanto en la portada, como en la sección propia de las primeras páginas ("Enfoque") y en las de los Juegos, donde hay un gran despliegue gráfico con alarde de maquetación. Aparecieron 109 imágenes de las hispanas (31 más que en Pekín), una marca nunca vista antes. La más retratadas en esta ocasión fue Mireia Belmonte (14 veces).

En las portadas hubo presencia olímpica casi a diario (18 de las 19 analizadas), dos más que en Pekín, y femenina en diez de ellas (dos más). Las españolas aparecieron con foto en seis portadas (dos de Mireia y una de Maialen, Carbonell-Fuentes, Marina y el trío de vela).

Las estrellas de los Juegos volvieron a ser el atleta Usain Bolt, el nadador Michael Phelps, el "Dream Team" de la NBA y los españoles de baloncesto.

\subsubsection{Análisis cuantitativo}

Del total de espacio dedicado a la información olímpica en $\mathrm{ABC}$ en Londres $2012\left(226.125 \mathrm{~cm}^{2}\right)$, se dedicaron a las mujeres $51.721 \mathrm{~cm}^{2}$, lo que supone un $22,87 \%$ de lo publicado. El total de mujeres participantes fue de 113 , en una expedición de 282 personas $(40,07 \%)$.

\section{CONCLUSIONES}

La evolución social y deportiva de nuestro país a lo largo del último siglo ha sido fundamental para conseguir los logros de los que hoy disfrutamos. Las mujeres se han ganado su espacio en la sociedad con mucho esfuerzo, rompiendo moldes, y eso es digno de alabar.

A pesar de que hasta hace bien poco existían incluso impedimentos de todo tipo para que las mujeres hicieran deporte, la mejoría sociopolítica del país hizo que cada vez más féminas se incorporaran al de alta competición. Si a esto se le añade la explosión deportiva que supuso la celebración de los Juegos Olímpicos en Barcelona en 1992, la semilla del deporte femenino ya estaba en plena germinación 
para que las "guerreras" del siglo XXI lograran más medallas que los hombres en los de Londres (ver figura 1).

Por tanto, como primera conclusión podemos afirmar que, a mayor evolución social, mayor número de participantes.

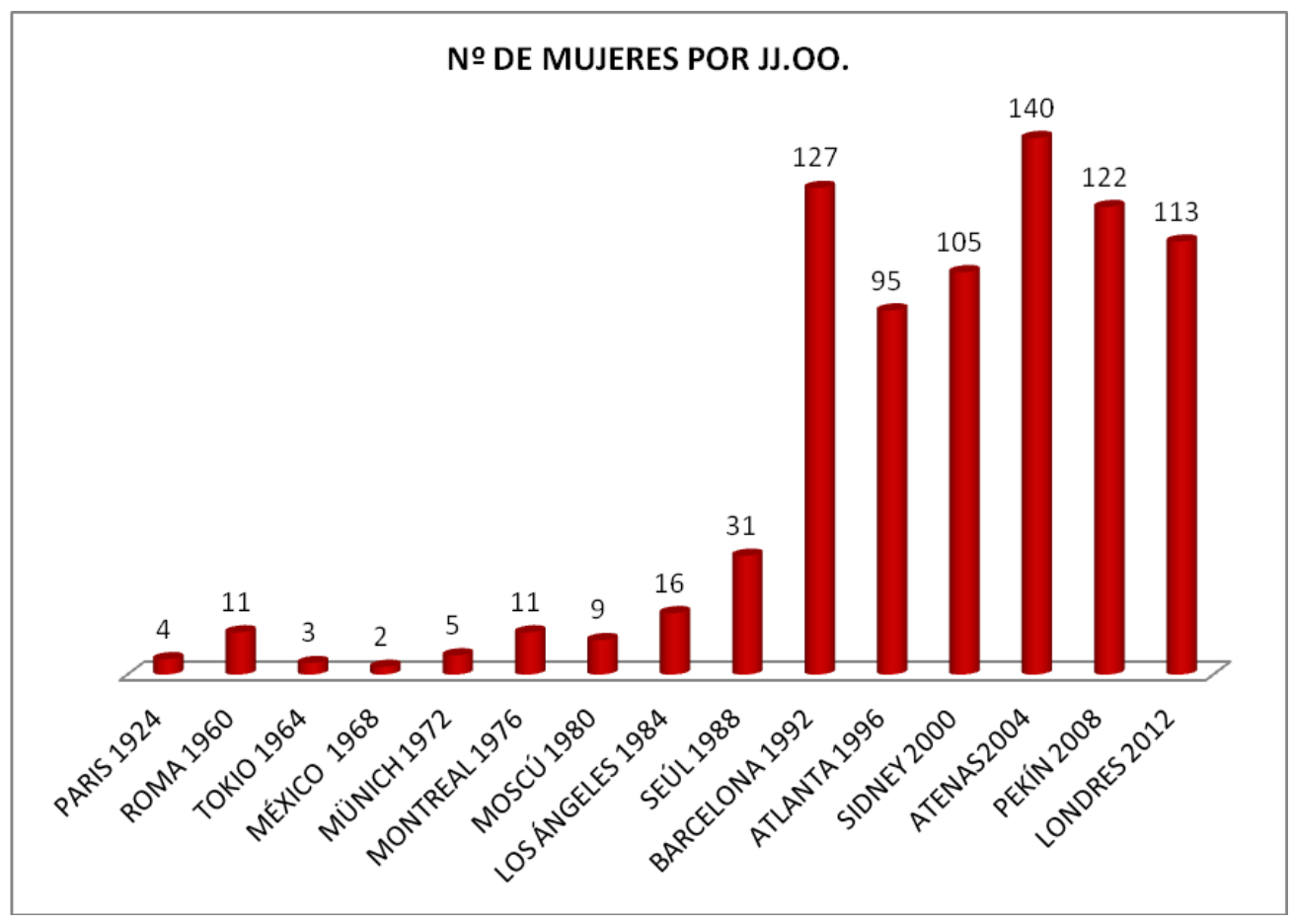

Figura 1. No de Mujeres por JJ.OO. Fuente: Comité Olímpico Español (COE).

Como si de una espiral ascendente se tratara, al integrarse las mujeres en el tejido deportivo de una manera más intensa se produce una mayor base de practicantes. En consecuencia, de la cantidad sale la calidad y el número de deportistas de alto nivel también aumenta, lo que se refleja en el número de participantes en las ediciones olímpicas.

También es muy importante que las niñas que se interesan por el deporte tengan unos referentes claros en los que mirarse, unas heroínas a las que parecerse. La imagen ganadora que transmitió Arantxa Sánchez-Vicario en su momento o la actual de Mireia Belmonte hacen mucho en este sentido, porque compiten por méritos propios con los hombres que copan el estrellato del deporte nacional. Y 
todo esto provoca nuevas vocaciones, sobre todo en deportes antes no tan destacados como el balonmano o el waterpolo, en los que se destaca más si cabe su espíritu de lucha y de entrega.

En el plano de la evolución social, también es importante que existan más mujeres fuera de la primera línea del deporte, es decir, de las propias deportistas. Hacen falta más dirigentes, entrenadoras, árbitras, patrocinadoras o periodistas que luchen desde dentro para seguir fomentando el deporte femenino. Esta labor de goteo se complementa con los Programas de Mujer y Deporte del Consejo Superior de Deportes y también tiene su repercusión en la difusión de los éxitos y en el aumento del interés por ellos.

En relación con esta mejora social y, como consecuencia, llega también la económica. A raíz de la inversión oficial en el mundo del deporte que se produjo con los planes ADO, las deportistas llevan años disfrutando de becas monetarias y de distintos privilegios que han hecho que se pudieran centrar exclusivamente en su preparación y mejoría.

De esta manera se justifica la explosión medallística femenina inicial que se produjo en 1992, cuando de golpe se obtuvieron ocho trofeos en Barcelona. En los siguientes años se fueron manteniendo con cierta estabilidad las cifras hasta que en Londres 12 se superaron todos los registros, con once (ver figura 2).

Como segunda conclusión podemos pues afirmar que a mayor número de participantes, mayores éxitos.

Como se ha visto en el análisis de las informaciones de los distintos JJ.OO. el camino ha sido costoso, pero constante. Es evidente la relación entre el número de participantes, el número de triunfos y la repercusión pública. Las medallas comenzaron a llegar en cuanto se alcanzó el centenar de olímpicas porque contaban con las ayudas precisas para prepararse. Y desde ese momento de Barcelona 92, la evolución no se ha parado hasta ahora.

Aunque son conscientes de que a la gloria es efímera, las atletas son ahora más conocidas, se las sigue en las redes sociales, las niñas las idolatran y eso es gracias a los medios. Es significativo el caso de Ruth Beitia, que está alargando su carrera deportiva al no cesar sus éxitos y aparece habitualmente en la portada de los diarios deportivos. Además, es la cabeza visible del atletismo español en general, la capitana tanto de los hombres como de las mujeres 


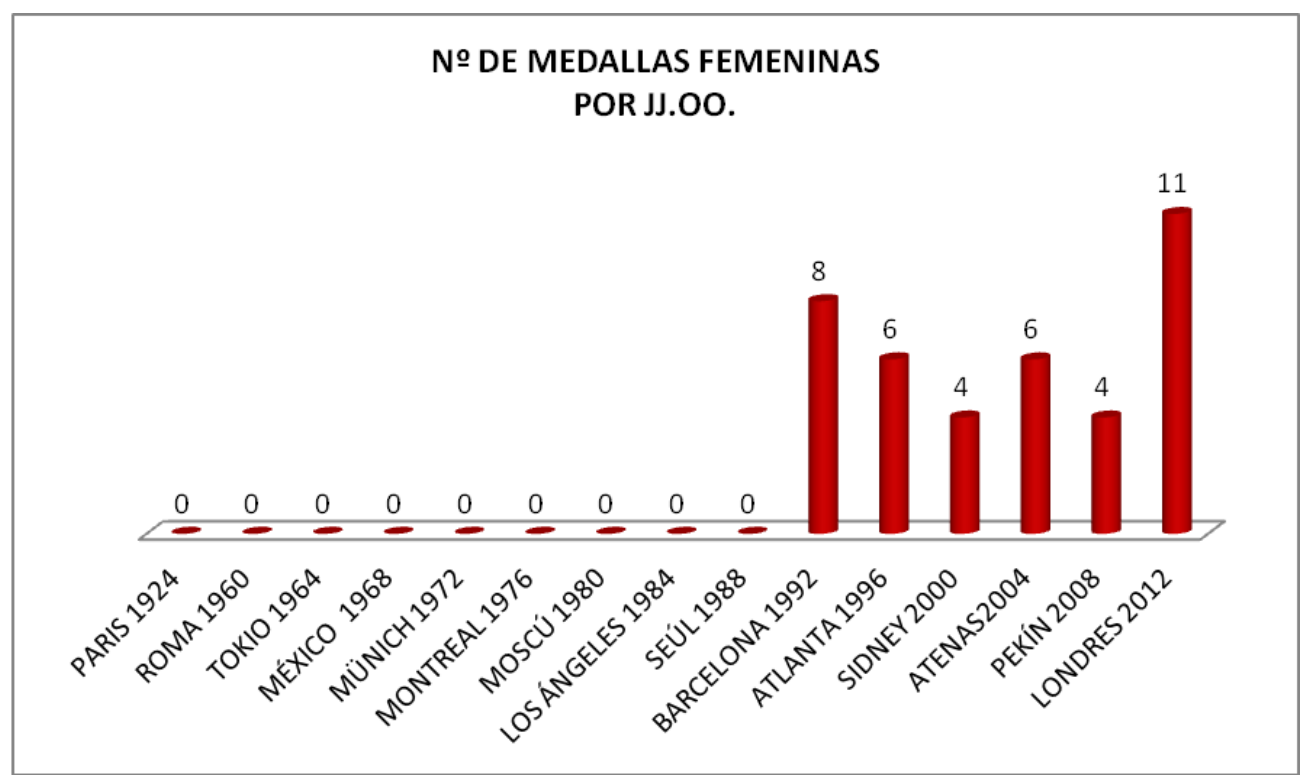

Figura 2. $\mathrm{N}^{\mathrm{o}}$ de medallas femeninas por JJ.OO. Fuente: COE.

Esto evidencia que A MÁS MEDALLAS, MÁS ESPACIO EN ABC. Cuando han llegado los triunfos los medios se han visto "obligados" a informar de ellos (ver figura 3).

Como tercera conclusión es evidente que a mayor número de medallas, mayor repercusión en $\mathrm{ABC}$.

Por lo que se refiere al espacio dedicado en $\mathrm{ABC}$, fue testimonial hasta que se empezaron a conseguir diplomas, y estable, a partir de la cita catalana. En los JJ.OO. más recientes se habían consolidado las cifras de repercusión entre el 13-15 $\%$ del total hasta que, en Londres, los éxitos obligaron a casi duplicar esas cifras $(22,87 \%)$; es decir, casi una de cada cuatro informaciones eran femeninas, cuando sólo dos de cada tres atletas eran féminas. Aún queda camino por recorrer, pero las bases son prometedoras.

Para ser noticia hay que tener buenos resultados y éstos propician una mayor repercusión mediática y fomentan nuevas aficiones. Es complicado salir de este círculo vicioso, sobre todo cuando se compite con un adversario tan poderoso como el fútbol, que acapara la mayor parte de las páginas deportivas. La irrupción de mujeres en lugares en los que habitualmente no habían estado llama mucho la 
atención y cuando ganan grandes competiciones ya se les trata igual que a los hombres.

Lo que quiere el lector es disfrutar con los triunfos y cuando éstos llegan, no importa si provienen del campo masculino o del femenino. El éxito vende por sí solo, independientemente de quién lo logre.

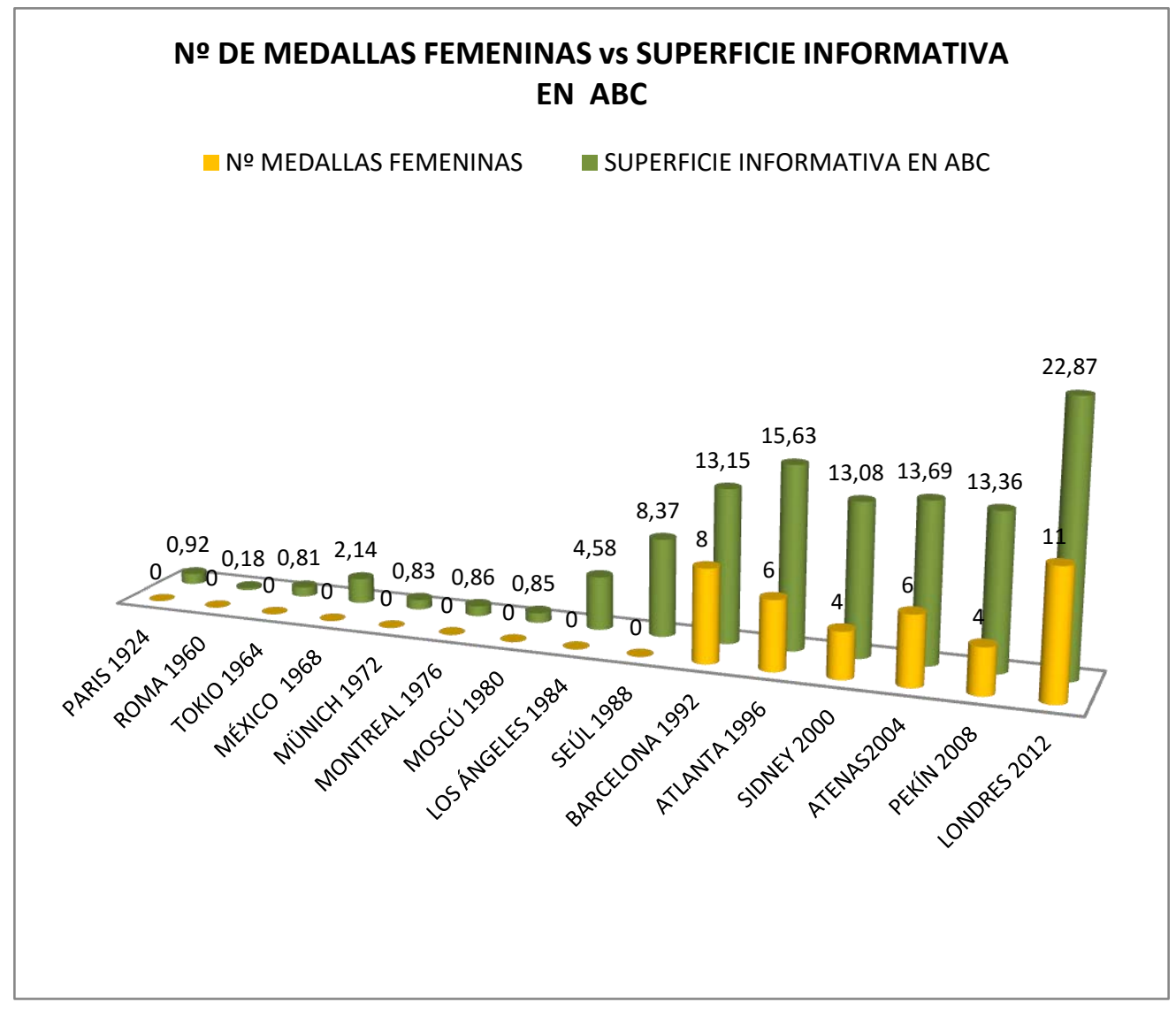

Figura 3. $\mathrm{N}^{\mathrm{o}}$ de medallas femeninas vs superficie informativa en ABC. Fuente: Elaboración propia del autor. 


\section{BIBLIOGRAFÍA}

- Alcoba, Antonio (1992). España en los Juegos Olímpicos. Madrid: Lerko Print.

- Alfaro Gandarillas, Élida (2008). Mujer joven y deporte, en Mujeres jóvenes en el siglo XXI, Revista de Estudios de Juventud, número 83. Madrid: Instituto de la Juventud, pp. 119-141.

- Angulo Aguado, Marta y Prieto Velasco, Antonio (2001). Participación de las mujeres en la alta competición, en Las mujeres en la alta competición deportiva, ICD número 30. Madrid: Consejo Superior de Deportes, pp. 39-60.

- Barbero González, Miguel Ángel (2015). Tratamiento informativo del deporte femenino español en los Juegos Olímpicos de Verano en el Diario ABC (19242012). Tesis doctoral. Director: Fernando Peinado Miguel. Madrid. Departamento de Filología Española III, Universidad Complutense de Madrid, 2015.

- Barrero, José (Coord.) (2010). Sdf: solo deporte femenino. Madrid: Fragua.

- Beato Ortega, E.; Diego García, O.; Dorrego Beneitez, A.; Plata de Toro, A. y Ribas Castromiño, L. (2001). La participación de las mujeres españolas en los JJ. OO. de Sydney, en Las mujeres en la alta competición deportiva, ICD número 30. Madrid: Consejo Superior de Deportes, pp. 111-128.

- Boulogne, Yves-Pierre (2000). Pierre de Coubertin y el deporte femenino. Revista Olímpica XXVI-31, Lausana, pp. 23-26.

- Cagigal, J. M. (1981). Oh! Deporte (Anatomía de un Gigante). Colección Kine. Valladolid: Miñón.

- Carta Olímpica (2003). Comité Olímpico Español. Página web. [consulta: 207-2006]. Disponible en http://www.coe.es

- Declaración de Brighton (1994). [consulta 23-11-14]. Disponible en: http://www.csd.gob.es/csd/estaticos/myd/declaracion-brighton.pdf

- Defrantz, Anita L. (1997). La evolución del papel de la mujer en los Juegos Olímpicos. Revista Olímpica XXVI-15, Lausana, pp. 18-21. 
- Fasting, Karl (1999). La mujer, el deporte y los medios de comunicación. Revista Olímpica XXVI-26, Lausana, pp. 43-45.

- Gazapo Andrade, Bienvenido (2010). Mujer y deporte en la historia. Una reflexión antropológica y sociológica. En Barrero, José (Coord.). Sdf: solo deporte femenino. Madrid: Fragua, pp. 29-53.

- Ibáñez, Eugenia (2001): Información sobre deporte femenino: el gran olvido. En Revista Apunts, Educación Física y Deportes número 65. Tercer trimestre, 2001 [consulta 27-12-14], pp. 111-113. Disponible en:

http://www.revista-apunts.com/es/hemeroteca?article=557\&highlight=ibañez

- Instituto de la Mujer (2006). Actitudes y Prácticas deportivas de las Mujeres en España (1990-2005). Instituto de la Mujer, 92. Madrid.

- Leiva Román, Ricardo (2012). Análisis de participación y resultados del Equipo Olímpico español en los Juegos Olímpicos de verano (1896-2008). Tesis doctoral. Directores: María José Martínez Patiño y José Antonio Pérez Turpin. Alicante. Facultad de Educación, Universidad de Alicante, 2012.

- López Díez, Pilar (2011). Deporte y mujeres en los medios de comunicación. Sugerencias y recomendaciones. Madrid: Consejo Superior de Deportes.

- Lopiano, Donna A. (2000). La mujer y del deporte moderno. Revista Olímpica XXVI-31, Lausana, pp. 54.58.

- Lyberg, Wolf (2000). La participación de las mujeres en los Juegos Olímpicos. Revista Olímpica XXVI-31, Lausana, pp. 46-53.

- Marín Fernández, Bernardo (Coord.) (1996b). Mujer y Deporte. Oviedo: Universidad de Oviedo.

- Moragas, Miguel de (1992). Los juegos de la comunicación. Las múltiples dimensiones comunicativas de los juegos olímpicos. Madrid: Fundesco.

- Moutawakel-Bennis El, Nawal. La irrupción de la mujer atleta. Revista Olímpica XXVI-15, Lausana, pp. 29-30.

- Olivera Betrán, Javier. Juegos Olímpicos Londres 2012: la olimpiada de las mujeres, en Apunts. Educación Física y Deportes, número 109. julio- 
septiembre 2012, pp. 7-10. [consulta 3-7-14]. Disponible en: http://www.revista-apunts.com/es/hemeroteca?article $=1547$

- Pfister, Gertrud. (2000). Las mujeres en los juegos y deportes tradicionales. Revista Olímpica XXVI-31, Lausana, pp. 38-45.

- Pfister, Gertrud. (2008). ¿Demasiado débil para correr? Las mujeres y el deporte en los discursos médicos desde los años veinte hasta los años sesenta. Citius, Altius, Fortius. Humanismo, Sociedad y Deporte: Investigaciones y ensayos, 1(2), pp. 39-68. Madrid: Centro de Estudios Olímpicos de la Universidad Autónoma de Madrid y Comité Olímpico Español.

- Puig i Barata, Nuria (2001). Itinerarios deportivos de las deportistas españolas, en Las mujeres en la alta competición deportiva, ICD número 30. Madrid: Consejo Superior de Deportes, pp. 27-38.

- Pujadas, Xavier (2011). Introducción, en Pujadas, Xavier (coord.). Atletas y ciudadanos. Historia social del deporte en España, 1870-2010. Madrid: Alianza Editorial. pp. 25-52.

- Ramajo, Natividad y Lallana del Río, Ibone. (2011). Olimpismo y estudios de género. En Mosaico olímpico. Investigación multidisciplinar y difusión de los estudios olímpicos. Barcelona: Centro de Estudios Olímpicos, Universitat Autónoma de Barcelona (2011) [consulta 27-12-14], pp. 181-188. Disponible en:

http://ceo.uab.es/2010/docs/C40912_2.pdf

- Samaranch, Juan Antonio (1997). Las mujeres en el movimiento olímpico, Revista Olímpica XXVI-15. Lausana, p. 3.

- Samaranch, Juan Antonio (2000). Mujer y deporte. Revista Olímpica XXVI31, Lausana, p. 3.

- Solano Moreno, Esperanza (2001). La alta competición femenina y los medios de comunicación, en Las mujeres en la alta competición deportiva, ICD número 30. Madrid: Consejo Superior de Deportes, 2001, pp. 105-109.

- Stefan, Maria D. (1997). Que vienen las atletas. Revista Olímpica XXVI-15, Lausana, pp. 22-25 
- Vigara Tauste, Ana María (2008). Periodismo deportivo en España: sexismo discursivo y discriminación de género, en Guerrero Salazar, Susana y Núñez Cabezas, Emilio Alejandro (coords.). Nuevas tendencias de la lengua española en los medios de comunicación. Málaga: VG Ediciones.

- VV. AA. (2011). Mosaico olímpico. Investigación multidisciplinar y difusión de los estudios olímpicos. Barcelona: Centro de Estudios Olímpicos, Universitat Autónoma de Barcelona. Disponible en:

http://ceo.uab.es/2010/docs/C40912_2.pdf

- Wilson, Wayne. Las mujeres en el deporte profesional, Revista Olímpica XXVI-31, Lausana, 2000, pp. 59-63.

- Zweifel, Françoise. Ser mujer en el Movimiento Olímpico, Revista Olímpica XXVI-15, Lausana, 1997, pp. 49-51. 